\title{
Analisis Edible Film dari Campuran Keratin dan Pati Jagung
}

\author{
Rina Mirdayanti ${ }^{1 *}$, Basuki Wirjosentono ${ }^{2}$, Eddy Marlianto ${ }^{3}$ \\ 1,2,3 Fakultas FKIP Fisika, Universitas Abulyatama,Jl. Blang Bintang Lama Km 8,5 \\ Lampoh Keude Aceh Besar \\ "Koresponden email: rinamirdani_fisika@abulyatama.ac.id
}

Diterima: 7 Juni 2018

Disetujui: 28 Agustus 2018

\begin{abstract}
The objectives of this research are to know the physical characteristics (water vapor transmission rate, water absorption), mechanical characteristics of edible film (maturation, tensile strength), morphology (functional group) and the edible film thermal properties made of corn starch and keratin. In this research, keratin extraction method of chicken feather waste is continued to know the influence of keratin preparation as filler material. Keratin concentration was used for each variation with comparison to corn starch matrix with keratin ie $0 \%, 3 \%, 5 \%, 7 \%$ and $9 \%$. In the research used type sorbitol plasticizer which is a sugar substitute compound that is non toxin. The data obtained from the results of the study in the analysis to see the properties of feeding for food packaging with a low rate of water vapor transmission with a value of $0.00334 \mathrm{~g} / \mathrm{cm} 2$ / day. From the testing of mechanical properties for tensile strength and elongation, the optimum percentage of keratin addition was $9 \%$ whose values were $25.02 \mathrm{MPa}$ and $3.64 \%$ respectively. Thermal analysis and functional groups with the addition of keratin increase the melting temperature and decomposition temperature by mixing physically. From all tests, the best percentage of keratin addition was found on the $9 \%$ keratin composition.
\end{abstract}

Keywords: Corn starch, Keratin, Edible fil, Analysis

Abstrak: Penelitian ini bertujuan untuk mengetahui karakteristik fisik (laju transmisi uap air, serapan air) , karakteristik mekanik edible film (pemanjangan, kuat tarik), morfologi (gugus fungsi) dan sifat termal edible film yang terbuat dari pati jagung dan keratin. Dalam penelitian dilakukan metode ekstraksi keratin dari limbah bulu ayam yang dilanjutkan untuk mengetahui pengaruh preparasi keratin sebagai bahan pengisi. Konsentrasi keratin yang digunakan untuk masing masing variasi dengan perbandingan terhadap matriks pati jagung dengan keratin yaitu $0 \%, 3 \%, 5 \%, 7 \%$ dan $9 \%$. Pada penelitian digunakan jenis plastisizer sorbitol yang merupakan senyawa pengganti gula yang bersifat non toksin. Data yang diperoleh dari hasil penelitian dianalisa untuk melihat sifat layak makan untuk kemasan makanan dengan laju transmisi uap air yang rendah dengan nilai sebesar $0,00334 \mathrm{~g} / \mathrm{cm}^{2} /$ hari. Dari pengujian sifat mekanik untuk kuat tarik dan kemuluran, persentase optimum penambahan keratin adalah sebanyak $9 \%$ yang nilainya masing-masing adalah $25,02 \mathrm{MPa}$ dan 3,64\%. Analisa termal dan gugus fungsi dengan penambahan keratin menaikkan temperatur leleh dan temperatur dekomposisi dengan pencampuran terjadi secara fisik. Dari keseluruhan pengujian, persentase penambahan keratin terbaik terdapat pada komposisi keratin $9 \%$.

\section{Pendahuluan}

Plastik merupakan bahan baru yang semakin berkembang. Pengembangan plastik berasal dari penggunaan material alami (seperti: permen karet, "shellac") sampai ke material alami yang dimodifikasi secara kimia (seperti: karet alami, "nitrocellulose") dan akhirnya ke molekul buatan-manusia (seperti: epoxy, polyvinyl chloride, polyethylene). Dewasa ini plastik banyak digunakan untuk berbagai macam bahan dasar (Wikipedia, 2013).

Penggunaan plastik di berbagai bidang didasarkan pada alasan bahwa bahan plastik mempunyai berbagai kelebihan. Diantaranya fleksibel (sesuai bentuk produk), transparan (tembus pandang), tidak mudah pecah (lentur), bentuk laminasi (dengan kombinasi bahan kemasan lain, aneka warna, tidak mudah rusak dan harganya relatif lebih murah serta mudah di dapatkan, sebagai contoh plastik kemasan makanan.

Plastik kemasan makanan yang sering dijumpai adalah yang terbuat dari produk polimer sintesis yang terbuat dari bahan-bahan 

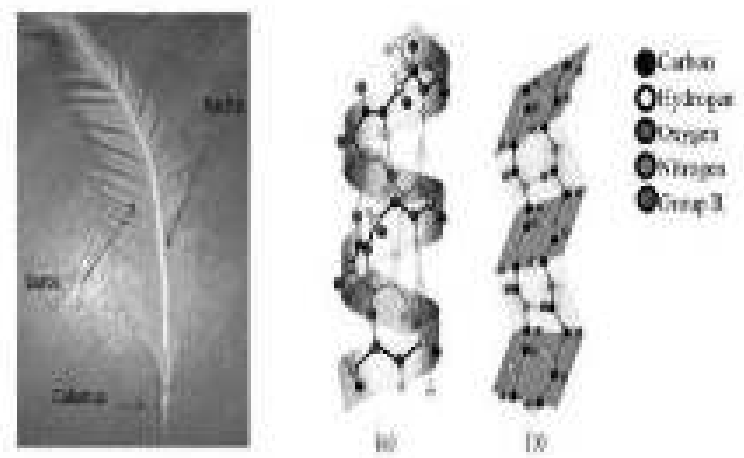

Gambar 1. Bagian bulu ayam dan struktur kimia (a) ahelik dan (b) $\beta$ sheet (Debora, at all. 2012)

petrokimia yang merupakan sumber daya alam yang tidak dapat di perbaharui. Struktur kimianya yang mempunyai bobot molekul tinggi dan pada umumnya memiliki rantai ikatan yang kuat, sehingga plastik membutuhkan waktu yang lama terurai di alam. Sampah plastik dapat bertahan hingga bertahun-tahun sehingga menyebabkan pencemaran terhadap lingkungan. Sampah plastik tidaklah bijak jika dibakar karena akan menghasilkan gas yang akan mencemari udara dan membahayakan pernafasan manusia, dan jika sampah plastik ditimbun dalam tanah maka akan mencemari tanah, air tanah. Plastik sendiri dikonsumsi sekitar 100 juta ton/tahun di seluruh dunia. Satu tes membuktikan $95 \%$ orang pernah memakai barang mengandung Bisphenol-A. Oleh karena itu pemakaian plastik yang jumlahnya sangat besar tentunya akan berdampak siqnifikan terhadap kesehatan manusia dan lingkungan karena plastik mempunyai sifat sulit terdegradasi (nonbiodegradable), dapat terdekomposisi (terurai) dengan sempurna. Dengan demikian pemakaian plastik baik plastik yang masih baru maupun sampah plastik haruslah menurut persyaratan yang berlaku agar tidak berbahaya terhadap kesehatan dan lingkungan (Karuniatuti, 2016). Oleh karena itu perlu adanya plastik kemasan makanan yang ramah lingkungan.

Edible film memberikan alternatif bahan pengemas yang tidak berdampak pada pencemaran lingkungan karena menggunakan bahan yang dapat diperbaharui dan harganya murah. Salah satu bahan utama pembuatan plastik biodegradable adalah pati (Darni, dkk, 2010). Polisakarida seperti pati dapat digunakan sebagai bahan baku pembuatan edible film karena ekonomis, dapat diperbaharui, dapat terdegradasi oleh alam menjadi senyawa- senyawa yang ramah lingkungan dan memberikan karakteristik fisik yang baik. Serealia seperti jagung merupakan salah satu sumber pati. Jagung memiliki persentase kandungan pati yang tinggi yaitu $90 \%$, penanamannya yang mudah, dan mudah didapatkan di Indonesia menjadikan jagung sangat potensial dijadikan sebagai bahan dasar edible film.

Disisi lain, bulu ayam juga menjadi masalah limbah yang cukup besar. Berdasarkan data Direktorat Jenderal Peternakan 2006, dapat dihitung produksi bulu ayam dari jenis ayam boiler sebanyak 25.690 ton (1999), 42.050 ton(2000), 49.250 ton (2001), 68.510 ton (2002), 72.680ton (2003) dan 72.775 ton (2005). Dari Risma Wisdawati pada tahun 2007 untuk daging ayam ras pedaging adalah sebesar 942.786 ton dan untuk daging ayam buras adalah sebesar 294.889 ton, sedangkan konsumsi daging ayam di seluruh indonesia pada tahun 2007 adalah sebesar 4,37 kg per kapita (Teknologi Pangan dan Gizi, 2007). Jumlah konsumsi ini merupakan yang terbesar di antara jenis daging lainnya. Besarnya produksi dan konsumsi ayam menghasilkan limbah dalam jumlah yang besar pula.

Pada dasarnya bulu ayam mengandung protein kasar yang sangat tinggi, yakni sebesar $74,4-91,8 \%$ dari bahan kering (Puastuti et al.,

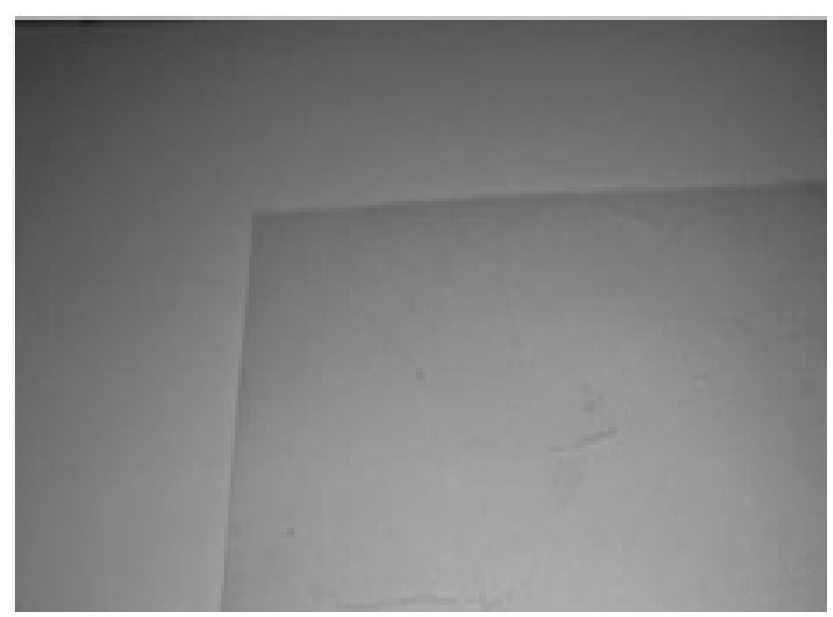

Gambar 2. Lapisan edible Film 


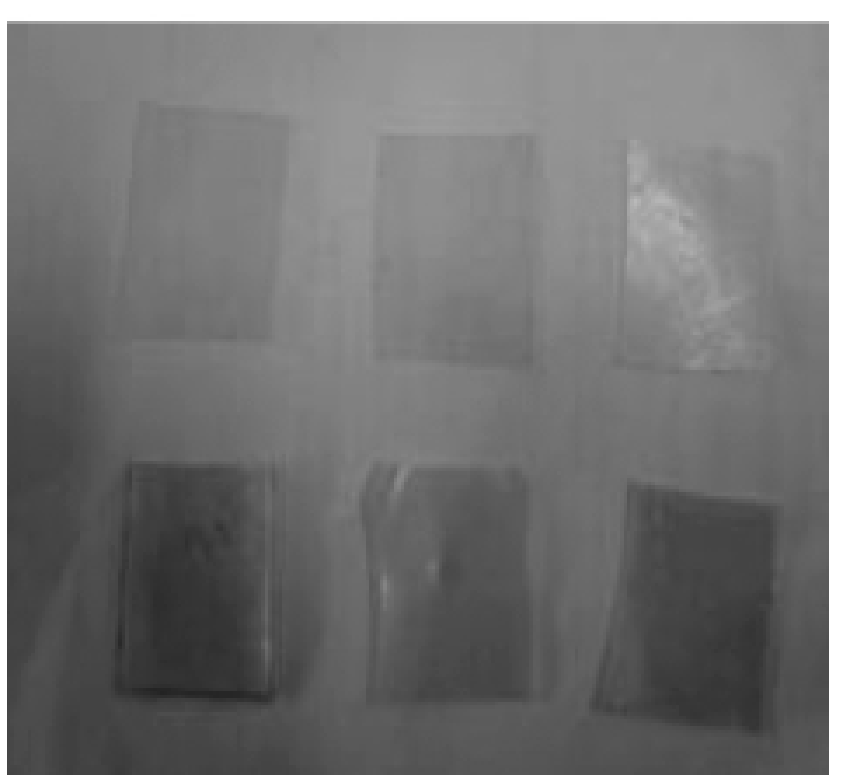

Gambar 3.Sampel uji serapan air

2004). Protein ini yang sebagian besar terdiri atas keratin yang digolongkan ke dalam protein serat. Keratin merupakan protein berserat yang terdapat dalam kandungan bulu ayam di harapkan dapat menjadi pengisi (filler) yang dapat digunakan dalam pembuatan edible film. Dengan penambahan sorbitol sebagai pemblastis dapat meningkatkan keelastisitas suatu bahan.

Protein ini yang sebagian besar terdiri atas keratin yang digolongkan ke dalam protein serat. Keratin yang diekstraksi dari limbah bulu ayam di harapkan selain memberikan kekuatan sifat mekanik juga dapat mengurangi volume dari limbah bulu ayam yang semakin lama semakin meningkat seiring dengan permintaan konsumen

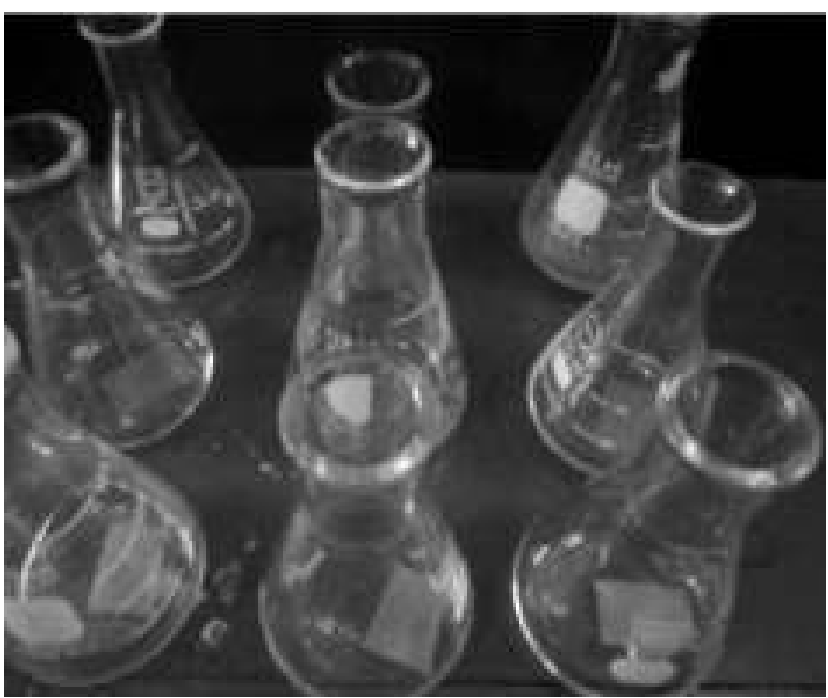

Gambar 4. Sampel uji sebelum perendaman

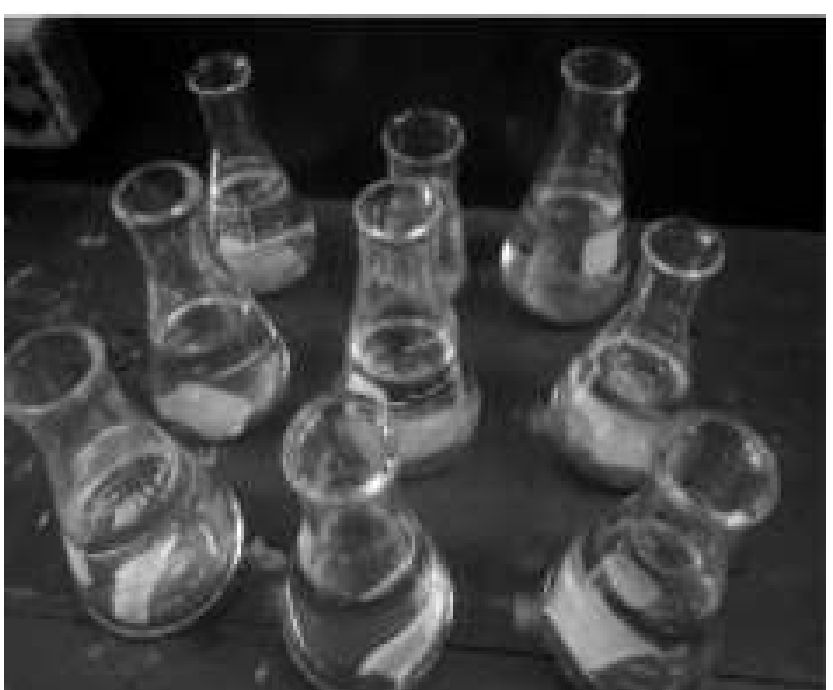

Gambar 5. Sampel uji setelah perendaman

akan kebutuhan daging ayam yang semakin tinggi. Sehingga limbah bulu ayam dapat termanfaatkan dengan optimal untuk di jadikan sebagai bahan dasar aplikasi film layak makan yang terbiodegradasikan. Tujuan penelitian ini untuk mengetahui karakteristik mekanik edible film pati jagung dengan pengaruh penambahan keratin dari limbah bulu ayam.

\section{Metode Penelitian}

Metode penelitian ini terdiri dari:

1) Alat Penelitian

Yang terdiri dari: Timbangan analitik, hotplate strirrer, alat-alat gelas, spatula, magnetik strirrer, ayakan 140 mesh, cetakan edible film, alat pompa vakum, oven pengeringan, alat sentrifugasi. Alat-alat pengujian antara lain : cawan WVTR, alat uji tarik, alat FTIR, alat uji termal

2) Bahan Penelitian

Bahan yang digunakan terdiri dari, Maizena, sorbitol, aquades, $\mathrm{Na} 2 \mathrm{~S}, \mathrm{HCl} 2 \mathrm{~N}$, bulu ayam, kalium hidroksida, tembaga sulfat.

3) Tahapan Penelitian

Tahapan penelitian ini terdiri dari dua proses meliputi proses ekstraksi keratin dari bulu ayam berdasarkan literatur yang di lakukan oleh (Krystyna wrzesniewska, 2007). Selanjutnya pembuatan Edible film dengan variasi konsentrasi $0 \%, 3 \%, 5 \%, 7 \%$ dan $9 \%$ keratin dari 10 gram pati jagung dan penambahan sorbitol 2 gram 
Tabel 1. Hasil perhitungan penyerapan air edible film untuk komposisi $0 \%$ Keratin dan 9\% Keratin.

\begin{tabular}{|c|c|c|c|}
\hline $\begin{array}{c}\text { Prepilrasi } \\
\text { ('‘) }\end{array}$ & $\begin{array}{l}\text { Besst } \\
\text { Kerings } \\
\text { (kir) }\end{array}$ & $\begin{array}{c}\text { Bcrat } \\
\text { Bissit। } \\
(\text { hip) }\end{array}$ & $\begin{array}{c}\text { Pressutas Air } \\
\text { yang Ierserap film } \\
\text { (oss) }\end{array}$ \\
\hline KIII & II,1K & $1,11 \overline{7}$ & 4144,44 \\
\hline $\mathrm{K} 112$ & $1,-11$ & 107 & 1114.52 \\
\hline $\mathrm{K} 02$ & 0,20 & 1.27 & 535.00 \\
\hline$R_{\text {illil }}-r_{i} \|_{j l}$ & $11, \%$ & 1,14 & $47 y, 6 h$ \\
\hline Kपا & 11.27 & 1.26 & $47 \%, 73$ \\
\hline $\mathrm{K} 92$ & $0,2-1$ & 1.11 & 187.50 \\
\hline $\mathrm{K} 93$ & 0,21 & 1,36 & 547.63 \\
\hline Rillit-radat & 11.7 & 1.34 & $5 \mid 1 \%+\%$ \\
\hline
\end{tabular}

sebagai plasticizer. Pengujian karakteristik fisik edible film meliputi serapan air, laju transmisi uap air. Karakteristik mekanik meliputi kuat tarik, kemuluran. Sifat marfologi dan termal meliputi gugus fungsi (FTIR) dan proses endoterm dan eksoterm dari suatu bahan.

\section{Hasil dan Pembahasan}

Edible film adalah lapisan tipis yang di buat dari bahan yang dapat di makan, diletakkan diantara komponen makanan yang berfungsi sebagai pembatas (barrier) terhadap transfer massa (misal kelembaban, oksigen, lipid dan zat terlarut) dan sebagai carrier bahan makanan dan aditif untuk meningkatkan penanganan makanan. (Teknologi Pangan dan Gizi IPB,1997).

Keuntungan dari edible film adalah dapat melindungi produk pangan, penampakan asli produk dapat dipertahankan dan dapat langsung dimakan serta aman bagi lingkungan (Nugroho, et all 2013). Ediblefilm dalam penelitian ini dibuat dari bahan dasar limbah bulu ayam yaitu keratin dengan konsentrasi 1\%, 3\%, 5\%, 7\% dan 9\% dari 10 gram pati jagung, $140 \mathrm{ml}(\mathrm{b} / \mathrm{v})$ aquadest dan penambahan sorbitol sebanyak $2 \mathrm{ml}$. Edible film tersebut selanjutnya dilakukan pengujian fisik, mekanik, morfologi, termal dan biodegradable

Tabel 2. Nilai serapan air terhadap Konsentrasi Keratin

\begin{tabular}{cc} 
Konscutrasi Koratio (\%) & Nilai serapan Air i"nj \\
\hline K0 & 474.66 \\
K9 & 510.62 \\
\hline
\end{tabular}

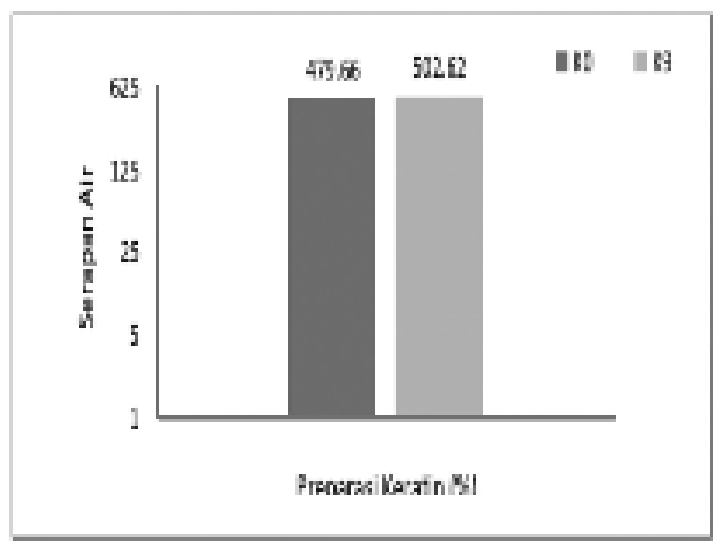

Gambar 6. Pengaruh preparasi keratin terhadap serapan air Edible Film

sehingga dapat diketahui karakteristik dari setiap pengujian ketiga bahan dasar tersebut.

\subsection{Hasil Visual Edible Film}

Film dengan komposisi keratin, pati jagung dan sorbitol menghasilkan film berupa padatan kering berwarna bening, sering bertambahnya keratin terjadi perubahan warna pada film yang dihasilkan.

\subsection{Hasil Serapan Air}

Uji serapan air di lakukan untuk mengetahui kemampuan serap air dari edible film yang di tunjukkan dengan perbedaan massa awal film dan massa film setelah menyerap air.

Contoh Perhitungan:

$$
\begin{aligned}
& \text { Serapan air }=\frac{m_{0-1}}{x} \times 100 \% \\
& \begin{array}{l}
=\frac{\text { su-vas }}{\sin }=100 \% \\
=479,66 \%
\end{array}
\end{aligned}
$$

Berdasarkan Tabel 2. terlihat bahwa kemampuan menyerap air yang dimiliki campuran konsentrasi

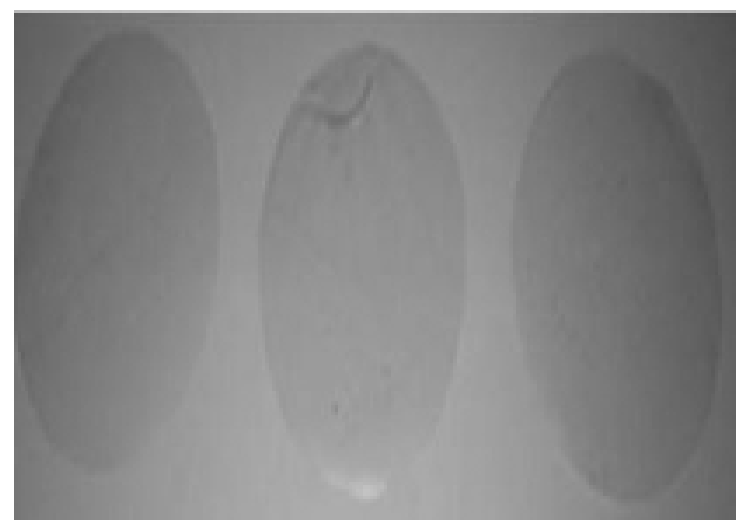

Gambar 7. Spesimen uji transmisi uap air 


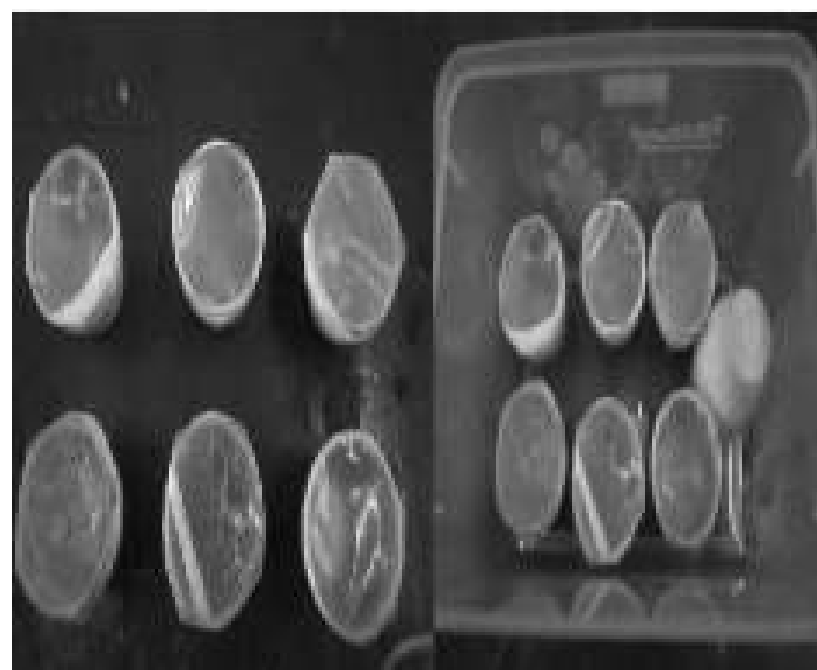

Gambar 8. Proses uji transmisi uap air dengan Metode Cawan.

9\% keratin lebih besar dari konsentrasi $0 \%$ keratin.

Dari hasil pengujian di peroleh nilai serapan air pada konsentrasi 9\% keratin sebesar 502, $62 \%$ dan konsentrasi pada $0 \%$ keratin dengan nilai sebesar $479,66 \%$.

Hasil analisis dari Gambar 6. terlihat bahwa kemampuan menyerap air yang dimiliki campuran konsentrasi 9\% keratin lebih besar dari konsentrasi $0 \%$ keratin. Dari hasil pengujian di peroleh nilai serapan air pada konsentrasi 9\% keratin sebesar 502, $62 \%$ dan konsentrasi pada $0 \%$ keratin dengan nilai sebesar 479,66\%. Hasil analisis gambar menunjukkan tingkat penyerapan air dari film dengan penguat 9\% wt keratin dan film dengan penguat $0 \%$ keratin.

Penambahan bahan penguat keratin menunjukkan tingkat serapan air yang lebih tinggi dibandingkan dengan tanpa bahan pengisi $0 \% \mathrm{wt}$ keratin. Hal tersebut terjadi karena kandungan pengisi yang meyebabkan terbentuknya pori semakin besar sehinggamengakibatkan penyerapan air yang lebih besar.

Tabel 3. Pengukuran permeabilitas uap air edible film dengan komposisi $0 \%$ Keratin

\begin{tabular}{|c|c|c|c|}
\hline $\begin{array}{l}\text { Siaktu } \\
\text { gaminj }\end{array}$ & $\begin{array}{l}\text { Boos: } \\
\text { S(itiats }\end{array}$ & $\begin{array}{c}\text { Kelilangan Bobot } \\
\text { (Cirani }\end{array}$ & Wrik \\
\hline 0 & $20,-4$ & & \\
\hline 24 & 26,1 & 0,09 & ח, \\
\hline 24 & 26,20 & 0,04 & $0,006 \mathrm{~s}=7$ \\
\hline 24 & $2 \sigma_{1}, 29$ & 0.05 & $0,0.03$ \\
\hline 24 & 26.27 & 0,192 & (1.191]76 \\
\hline
\end{tabular}

Tabel 4. Pengukuran permeabilitas uap air edible film dengan komposisi $9 \%$ Keratin

\begin{tabular}{|c|c|c|c|}
\hline $\begin{array}{l}\text { Wraklu } \\
\text { (jamj }\end{array}$ & $\begin{array}{l}\text { Tholvot } \\
\text { (Citami }\end{array}$ & $\begin{array}{c}\text { Kehiliriegrn } \\
\text { Bobot (Ciram) }\end{array}$ & WVIR \\
\hline () & 28,410 & & \\
\hline 24 & 28,99 & 0,01 & 0,0 ? \\
\hline 34 & 28,19 & 0,01 & 7, \\
\hline 24 & 28,37 & 0.03 & 0,00500 \\
\hline 34 & 28,37 & 0,03 & 0,001500 \\
\hline
\end{tabular}

\subsection{Hasil Laju Transmisi Uap Air}

Laju transmisi uap air adalah jumlah uap air yang dapat melalui bahan pengemas dan merupakan salah satu faktor penting dalam pengemasan produk pangan karena berhubungan erat dengan umur simpan produk. Daya tembus film oleh uap air dapat diketahui dengan melakukan analisis transmisi uap air. Pengujian sifat suatu kemasan terhadap transmisi uap air dengan metode cawan mengikuti standar ASTM E-96 (Lastri yanto et all., 2007). Pengukuran laju transmisi uap air dilakukan selama 24 jam selama 4 hari.

Contoh Perhitungan:

$$
\begin{gathered}
\text { WVTR }=\frac{\text { Bobot Air yang Hilang }}{\text { Waktu } x \text { Luas }} \\
\frac{0,03}{24 \times 0,6}=0,00075 \frac{\mathrm{gram}}{\mathrm{cm}^{2}} / \mathrm{jam}
\end{gathered}
$$

Nilai dari hasil uji transmisi uap air setiap 24 jam pada konsentrasi 0\% keratin dan 9\% keratin di plot terhadap lamanya hari yang tunjukkan pada Gambar 9.

Tabel 5. Hasil uji laju transmisi uap air

\begin{tabular}{|c|c|c|}
\hline $\begin{array}{l}\text { Konsentrasi } \\
\text { keratin }(\%)\end{array}$ & Hari ( لlam) & 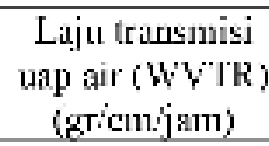 \\
\hline \multirow{4}{*}{$\mathrm{KO}$} & 1 & $5 \times 10^{2}$ \\
\hline & 2 & $66,7 \times 10^{4}$ \\
\hline & 3 & $83,3 \times 10^{1}$ \\
\hline & 1 & $116,7 \times 11^{-4}$ \\
\hline \multirow{4}{*}{$K 9$} & $\mathrm{l}$ & $16,7 \times 10^{-1}$ \\
\hline & 2 & $16,7 \times 10^{4}$ \\
\hline & 3 & $5 \times 10^{3}$ \\
\hline & 4 & $5 \times 10^{3}$ \\
\hline
\end{tabular}
setiap 24 jam selama 4 hari 
Tabel 6. Hasil uji wvtr edible film dengan

Keratin 9\% dan 0\% Keratin

\begin{tabular}{|c|c|}
\hline $\begin{array}{c}\text { Preperusi } \\
\text { Kemalin (U/1) }\end{array}$ & 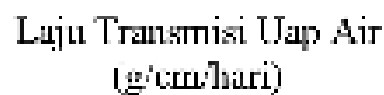 \\
\hline $\mathrm{K} 0$ & $11(x) 792$ \\
\hline$K y$ & $11(X) 334$ \\
\hline
\end{tabular}

Kemudian nilai rata-rata dari hasil uji transmisi uap air $(\mathrm{g} / \mathrm{cm} /$ hari) diplot terhadap konsentrasi keratin (yang di tunjukkan pada Gambar 10).

Hasil analisis gambar terlihat bahwa edible film dengan 9\% keratin mempunyai nilai laju transmisi uap air yang rendah, dengan nilai laju transmisi uap air sebesar $44,5 \times 10^{-4}\left(\mathrm{~g} / \mathrm{cm}^{2} /\right.$ hari) sebab pada kondisi tersebut film memiliki nilai yang lebih kecil dibandingkan film dengan konsentrasi 0\% keratin. Yaitu, sebesar 105,6×10${ }^{4}\left(\mathrm{~g} / \mathrm{cm}^{2} /\right.$ hari $)$. Terlihat bahwa film yang paling baik digunakan sebagai kemasan yaitu film dengan konsentrasi keratin 9\%, dengan nilai laju transmisi uap air sebesar44,5x $10^{-4}\left(\mathrm{~g} / \mathrm{cm}^{2} /\right.$ hari) sebab pada kondisi tersebut film memiliki nilai yang lebihkecil di bandingkan film dengan konsentrasi 0\% keratin.

Dari Gontard, 1993, menyebutkan bahwa, migrasi uap air umumnya terjadi pada bagian film yang hidrofilik. Dengan demikian ratio antara bagian yang hidrofilik dan hidrofobik komponen film akan mempengaruhi nilai laju transmisi uap air film tersebut. Semakin besar hidrofobitas film, maka nilai laju transmisi uap air film tersebut akan semakin menurun(Rachmawati, 2009). Dalam hal

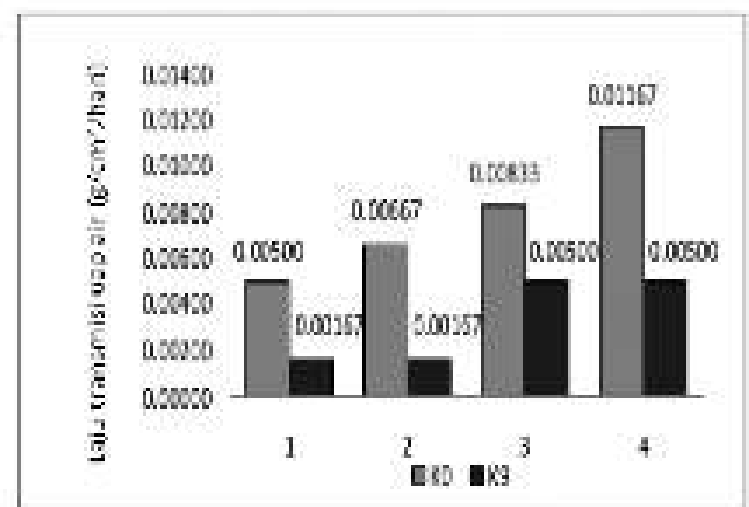

Gambar 9. Pengaruh Waktu Terhadap Transmisi Uap Air Edible Film

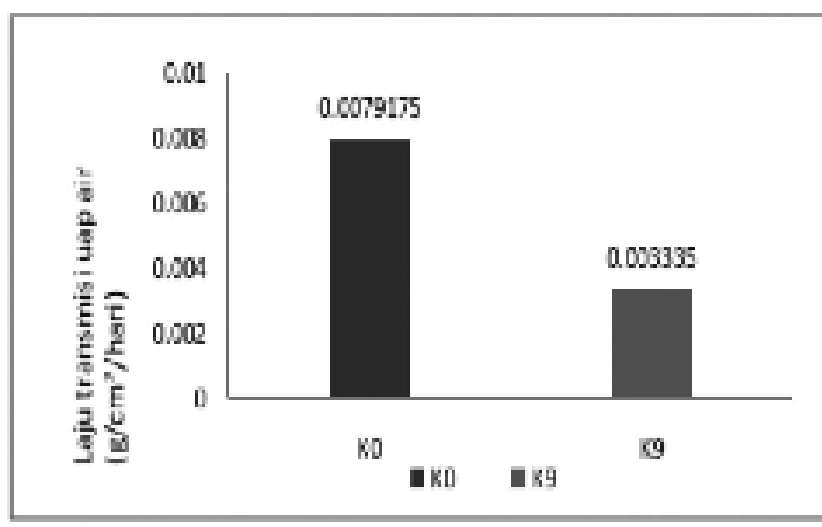

Gambar 10. Nilai transmisi uap air terhadap konsentrasi Keratin.

ini keratin merupakan protein serat yang bersifat hidrofobik, sehingga peningkatan konsentrasi keratin cenderung menurunkan laju transmisi uap air edible film. Apabila di bandingkan dengan edible film dari campuran $0 \%$ keratin yang memiliki laju transmisi uap air sebesar 105,6×10${ }^{4}\left(\mathrm{~g} / \mathrm{cm}^{2} /\right.$ hari $)$ maka edible film dengan berpengisi keratin $9 \%$ ini memiliki kemampuan dalam menahan laju transmisi uap air yang lebih besar.

\subsection{Hasil Uji Sifat Mekanik}

Pengujian ini bertujuan untuk mengetahui karakteristik sifat mekanik edible film yang terbentuk dengan variasi komposisi penguat keratin. Pengujian sifat mekanik di lakukan di laboratorium penelitian yang mengacu pada ASTM D638.

Tujuan dari pengujian sifat mekanik pada tahap ini adalah untuk mengetahui karakteristik sifat mekanik terbaik dari edible film dengan variasi preparasi penguat $0,3,5,7$ dan $9 \% \mathrm{wt}$ keratin. Sifat mekanik yang di uji disini meliputi, kekuatan tarik dan kemuluran.

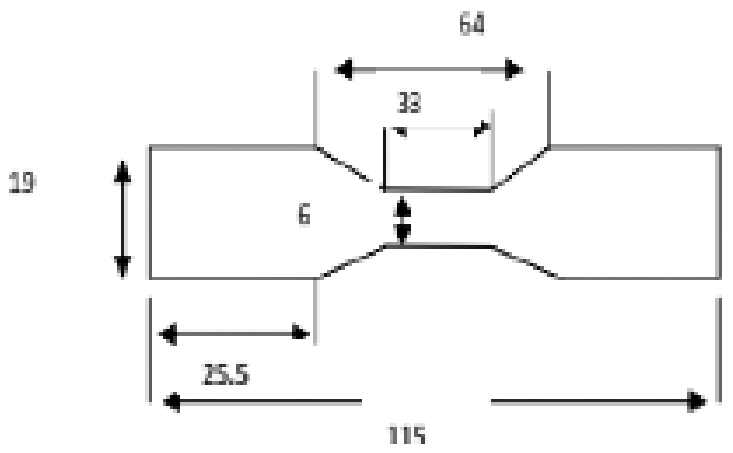

Gambar 11. Spesimen Uji Kekuatan Tarik Berdasarkan ASTM-638. 


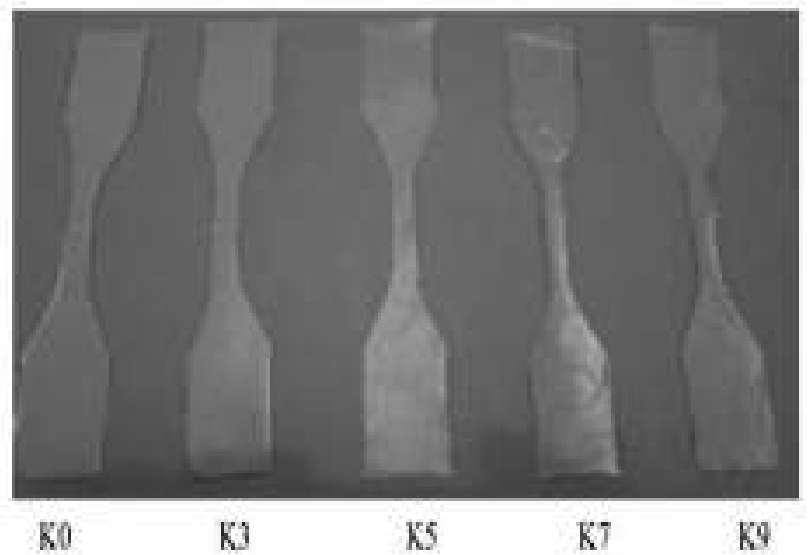

Gambar 12. Spesimen uji tarik pada variasi Komposisi Keratin.

Campuran pati jagung dengan variasi komposisi keratin yang berbeda merupakan faktor penting untuk menentukan sifat mekanis bahan yang di inginkan. Hasil dari pengujian di dapat load dan stroke. Harga load dalam satuan $\mathrm{kgf}$ dan stroke dalam satuan $\mathrm{mm}^{2}$. Hasil pengujian ini diolahkembali untuk mendapatkan nilai kekuatan tarik dan kemuluran. Perhitungan dengan menggunakan rumus berikut:

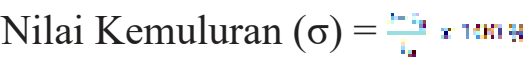

Keterangan:

$$
=\frac{a t}{r_{2}} \times 200 \pi
$$

lo = Panjang spesimen mula-mula $(\mathrm{mm})$

$1=$ Panjang spesimen setelah diberikan beban hingga putus $(\mathrm{mm})$

$\mathrm{e}=$ Kemuluran (perpanjangan)

$\Delta \mathrm{l}=$ Pertambahanpanjang $(\mathrm{mm})=$ stroke

Contoh perhitungan:

Sampel spesimen 10 gr pati jagung di tambah 0,9 gr keratin mempunyai panjang mula-mula 64

Tabel 7. Hasil uji kuat tarik dengan variasi komposisi keratin.

\begin{tabular}{|c|c|c|c|c|c|c|}
\hline \multirow[b]{2}{*}{ Vi: } & \multirow[b]{2}{*}{$\begin{array}{c}\text { Vist:a } \\
\text { xi }\end{array}$} & \multicolumn{3}{|c|}{ Kompusisi } & \multirow[b]{2}{*}{ 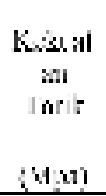 } & \multirow[b]{2}{*}{ 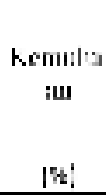 } \\
\hline & & $\begin{array}{c}\text { lal } \\
\text { JaLec } \\
\frac{8}{2} \\
\operatorname{sinm}\end{array}$ & $\begin{array}{c}\text { Suliu } \\
\text { a } \\
\text { senny }\end{array}$ & $\begin{array}{l}\text { Kural: } \\
\pi \\
\text { icmm }\end{array}$ & & \\
\hline 1 & Ki) & 10 & 2 & 0 & $15,1: 4$ & S1.9 \\
\hline 2 & K? & 10 & 2 & 0,7 & 10,19 & 2,21 \\
\hline 3 & $\mathrm{~K}^{5}$ & 10 & 2 & 0,5 & 16,79 & 3,27 \\
\hline 4 & $\mathrm{~K} Z$ & 10 & 2 & 0,7 & 18,37 & 5,65 \\
\hline 5 & K9 & 10 & 2 & 0,4 & $2.5,1.2$ & .8 .4 \\
\hline
\end{tabular}

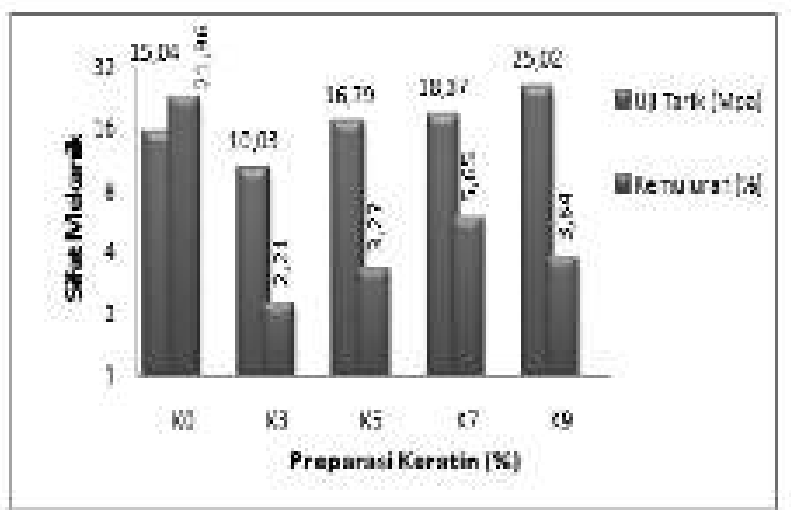

Gambar 13. Pengaruh komposisi keratin terhadap kuat tarik dan kemuluran Edible Film

$\mathrm{mm}$, harga stroke 2,33 mm maka kemulurannya:

Kemuluran (e) $=\frac{3,38}{c_{4}} \times 100 \%=3,64 \%$,

Harga kekuatan tarik di hitung dengan rumus :

Kekuatan tarik $(\sigma)=\frac{\text { F Maks }}{A_{0}}$

Keterangan

$(\sigma)=\frac{\text { Load }}{A_{0}}$

$\sigma \quad=$ Kekuatan tarik bahan $(\mathrm{MPa})$

$\mathrm{F}$ maks $=$ Gaya maksimum $(\mathrm{kgf})=$ Load

$A_{0} \quad=$ Luas penampang bahan $\left(\mathrm{mm}^{2}\right)$

tebal spesimen $(\mathrm{mm}) \times$ lebar

spesimen $(\mathrm{mm})$

Contoh Perhitungan:

Sampel uji mempunyai tebal $=0,1 \mathrm{~mm}$ dan lebar $=6 \mathrm{~mm}$, maka: $A_{0}=0,1 \mathrm{~mm}$ x $6 \mathrm{~mm}=0,6 \mathrm{~m}^{2}$ dan harga load $=1,53 \mathrm{kgf}$, maka harga kekuatantarik diperoleh :

Kekuatan Tarik $(\sigma)=\frac{1,53 \mathrm{Kgf}}{0,6 \mathrm{~mm}^{2}}$

$$
\begin{aligned}
& =2,55 \mathrm{Kgf} / \mathrm{mm}^{2} \\
& =25,02 \mathrm{MPa}
\end{aligned}
$$

Pada Tabel 7. memberikan informasi bahwa sifat mekanis film, variasi campuran yang optimum adalah pada variasi ke lima, yaitu pada 9\% keratin dengan kekuatan tarik 25,02 Mpa dengan kemuluran 3,64 \%. yaitu 21,96\%.

Nilai rata-rata dari hasil uji mekanik kuat tarik dan kemuluran dan di plot terhadap konsentrasi keratin yang tunjukkan pada Gambar 13 .

Hasil analisis Gambar13. dapat dilihat bahwa komposisi 9\% keratin memberikan harga kekuatan tarik maksimum sebesar 15,04 MPa dan kemuluran 3,64\%. Perubahan sifat mekanik ini berhubungan dengan interaksi keratin dengan pati dan juga sorbitol sebagai plasticizer. Selama proses 
Tabel 8. Hasil analisis sifat termal spesimen edible film

\begin{tabular}{|c|c|c|c|}
\hline Spasimen & $\begin{array}{l}\text { Terperaut } \\
\text { Trumsisi fielas } \\
\text { rCoflet }\end{array}$ & $\begin{array}{c}\text { Termperiutur didih } \\
\text { (cic:) }\end{array}$ & $\begin{array}{l}\text { Tyruperilur } \\
\text { Mak:ilmum } \\
\text { SCl(TM) }\end{array}$ \\
\hline Kevtilliu & $\mathrm{Hi}^{\circ} \mathrm{C}$ & $12 \mathrm{O}^{\circ} \mathrm{C}$ & $475.574 \times$ \\
\hline $\begin{array}{l}\text { Patj: Sorbirol } \\
\text { listi: Sumbilpl }\end{array}$ & - & $2900 \mathrm{C}$ & $440^{2} \mathrm{C}$ \\
\hline KelialıI & 71 & 34010 & $4 \sin 0^{\circ}$ \\
\hline
\end{tabular}

interkalasi, partikel pengisi/penguat akan masuk dan berikatan dengan lapisan permukaan matrik polimer. (Marbun, 2012). Hal ini dipengaruhi oleh jumlah komponen-komponen penyusun film.

Keratin sebagai biopolimer yang dicampurkan ke dalam pati dapat memberikan kekuatan mekanik yang lebih baik. Seiring bertambahnya konsentrasi keratin dapat menyebabkan peningkatan affinitas, sehingga memberi pengaruh terhadap sifat mekanik film.

\subsection{Hasil Uji Sifat Termal}

Termal analisa mempelajari sifat-sifat termal dari suatu bahan (sampel) yaitu perubahan yang terjadi apabila bahan dipanaskan. Dengan merubah temperatur suatu bahan yang di uji berbagai perubahan akan di alami bahan-bahan tersebut. Perubahan dapat di amati dalam perubahan temperatur $(\Delta \mathrm{T})$ pada saat bahan mengalami perubahan wujud. Dalam analisis DTA sampel dipanaskan menggunakan pemanas yang sama bersama senyawa pembanding $\left(\mathrm{Al}_{2} \mathrm{O}_{3}\right)$ yakni senyawa yang tidak mengalami perubahan selama pemanasan.

Tabel 9. Perbandingan plastik biodegradable dan film campuran pati jagung dan keratin terhadap sifat termal

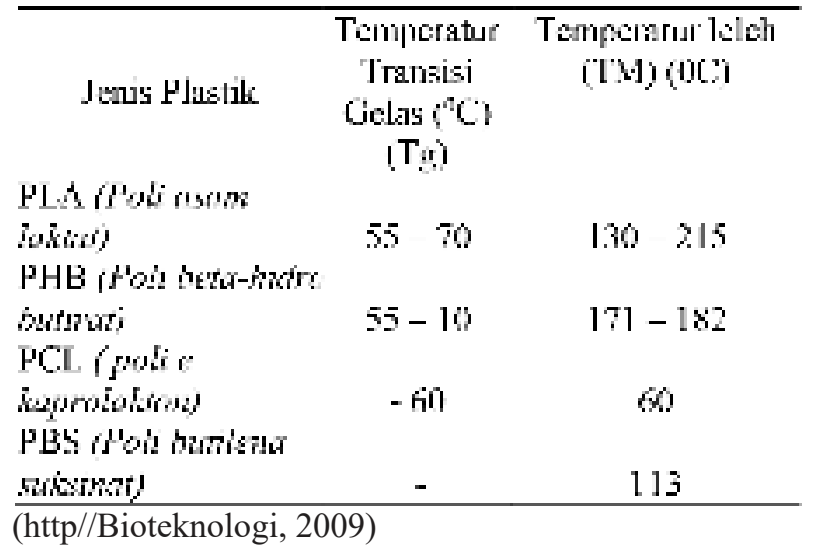

Berdasarkan Tabel 8. terlihat adanya perbedaan yang signifikan, perbedaan ini terjadi akibat adanya perpaduan antara pati, sorbitol dan keratin pada campuran film. Hal ini juga berdasarkan karakteristik keratin sebagai pengisi yang memberi pengaruh terhadap temperatur transisi gelas, titik leleh dan temperatur maksimum film. Terlihat terjadi penurunan temperatur transisi gelas ketika penambahan keratin dan menaikkan temperatur leleh dan temperatur dekomposisi. Temperatur leleh untuk film pati jagung berpengisi keratin memberikan sifat termal yang lebih baik dari plastik biodegradabel secara komersial.

\subsection{Hasil Uji Marfologi (FTIR)}

Spektrum FT-IR di ukur dengan menggunakan alat IR Shimadzu, bahan yang di analisis dengan pengujian FT-IR adalah Keratin sebagai filler, edible film dengan penguat $0 \%$ keratin dan edible film dengan penguat keratin $9 \%$ wt. Pengujian FTIR di gunakan untuk mengidentifikasi interaksi antara keratin sebagai penguat dan pati sebagai matrik. Spektrum FT-IR dari keratin, edible film

Tabel 10. Hasil analisa gugus fungsi spesimen campuran dari spektrum FT-IR

\begin{tabular}{|c|c|c|c|}
\hline Spesiuen & $\begin{array}{c}\text { Bilanean } \\
\text { Gelonbusis } \\
\text { (cm-) }\end{array}$ & $\begin{array}{l}\text { Guges } \\
\text { Fung,si }\end{array}$ & $\begin{array}{l}\text { Pusiaki } \\
\text { (Puviu ai } \\
\text { ob } 20 \text { । } \\
\text { and }\end{array}$ \\
\hline \multirow[t]{7}{*}{ Kerat in } & 1234.44 & $\begin{array}{c}\mathrm{C}-\mathrm{N} \\
\text { Anina }\end{array}$ & $\begin{array}{l}110111 \\
1350\end{array}$ \\
\hline & & Tskuk N- & $1550-$ \\
\hline & 1535.34 & $\begin{array}{c}\mathrm{H} \\
\mathrm{C}=\mathrm{O}\end{array}$ & $\begin{array}{l}1640 \\
610-\end{array}$ \\
\hline & 164.3 .35 & Anidu & 1670 \\
\hline & & Repanangan & $28.50-$ \\
\hline & $2062 .<\mathrm{k}$ & $\mathrm{C}-\mathrm{H}$ & 3000 \\
\hline & 1304 & Qugus O- & $\begin{array}{c}32010- \\
2500\end{array}$ \\
\hline \multirow{9}{*}{$\begin{array}{l}\text { Pali- } \\
\text { Sorbitol I } \\
\text { Katatin }\end{array}$} & ......... & & \\
\hline & & $C-N$ & 10101 - \\
\hline & 1118.71 & Anina & 1350 \\
\hline & & Regangan & 10111 \\
\hline & 1172.72 & $c-0$ & 1300 \\
\hline & & Regangan & 28511 \\
\hline & 206266 & $C-H$ & 3000 \\
\hline & & Sugus 0 & 331111 \\
\hline & .3541 .31 & $\mathrm{H}$ & 3600 \\
\hline \multirow{3}{*}{$\begin{array}{l}\text { Pati- } \\
\text { Sorbintal }\end{array}$} & 1727 & Regangal & $1000-$ \\
\hline & (1):- & Regangan & $2850-$ \\
\hline & 2947,23 & $\mathrm{C}-\mathrm{H}$ & 30000 \\
\hline
\end{tabular}




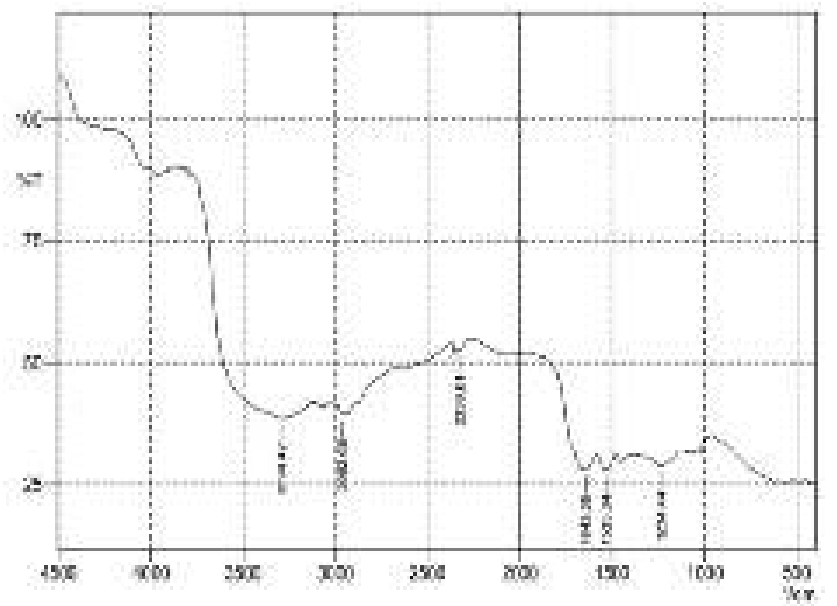

Gambar: 14. Spektrum FTIR Bahan Keratin

dengan penguat keratin $9 \% \mathrm{wt}$ dan edible film dengan penguat $0 \% \mathrm{wt}$. gelombang serapan $\left(\mathrm{cm}^{-}\right.$ ${ }^{1}$ ) dan sumbu y menunjukkan $\%$ transmisi.

Jika dilihat dari hasil uji FT-IR, maka terlihat beberapa gugus fungsi dari pencampuran bahan bahwa gugus fungsi pada edible film campuran pati jagung, sorbitol dan keratin (bahan pengisi) untuk bilangan gelombangnya tidak mengalami perubahan yang berarti. Hal tersebut berarti edible film yang dihasilkan merupakan proses blanding secara fisika karena tidak di temukannya gugus fungsi baru sehingga film memiliki sifat seperti komponen penyusunnya.

Berdasarkan pengujian gugus fungsi, keratin murni terlihat memiliki puncak(peak) yang lebih banyak yang muncul. Kemunculan banyak peak ini menunjukkan bahwa dalam keratin yang terbentuk terdapat banyak jenis ikatan. Dimana keratin merupakan suatu biopolimer yang mempunyai beberap agugus fungsi dominan, seperti kerbonil ester $(\mathrm{C}=\mathrm{O})$, ikatan polimerik C-O, O-H, dan C-H. (Syamsu, dkk, 2015)

Analisa spektrum FT-IR hasil pencampuran pati dengan sorbitol dan keratin menunjukkan bahwa spektrum edible film dengan penambahan keratin, hampirseluruhnya merupakan polipaduan antara spektrum pada keratin dengan campuranpati dan sorbitol. Pada pita serapan pada panjang gelombang 1118,71 cmdan1172,72 juga menandakan adanya gugus fungsi $\mathrm{C}-\mathrm{N}$ Amina dan regangan $\mathrm{C}-\mathrm{O}$. Selanjutnya pada panjang gelombang $2962,66 \mathrm{~cm}^{-}$ ${ }^{1}$ adanya gugus fungsi reganganC-H. Dan munculnya gugus $\mathrm{O}-\mathrm{H}$ dengan intensitas penyerapan yang luas ditunjukkan pada pita serapan dengan panjang gelombang $3541,31 \mathrm{~cm}^{-1}$.

\section{Kesimpulan}

Dari penelitian dapat diambil kesimpulan sebagai berikut: keratin dari limbah bulu ayam dapat digunakan sebagai bahan pengisi dalam pembuatan edible film. Karakteristik sifat mekanik terbaik edible film diperoleh pada preparasi 9\% wt keratin. Penambahan keratin sebagai komponen yang bersifat hidrofob mampu menurunkan laju transmisi uap air. Berdasarkan nilai laju transmisi uap air (WVTR) sebesar $0,00334 \mathrm{~g} / \mathrm{cm}^{2} /$ hari memungkinkan untuk dapat dijadikan sebagai bahan kemasan yang tahan terhadap umur simpan produk kemasan layak makan dan ramah lingkungan.

\section{Daftar Pustaka}

ASTM D-638-02 Standart test method for tensile properties of plastics. Philadelphia, PA : American Society for Testing and Material.

Darni, Y., Utami, H. (2010). Studi Pembuatan dan Karakteristik Sifat Mekanik dan Hidrofobisitas Bioplastik Dari Pati Sorgum. Jurnal rekayasa kimia dan lingkungan. Universitas Lampung. Skripsi, Teknik Kimia. Bandar Lampung: Universitas Lampung.

Debora, at.all. (2012). Physical and Morphological Structure of Chicken Feathers (Keratin Biofiber) in Natural, Chemically and Thermally Modified Forms, Materials Sciences and applications. Scientific Research.

Gontard,N.,Guilbert,S.,Cuq.J.L.,1993. Water and Glyserol as plasticizer Affect Mechanical and Water Barrier Properties at an Edible Wheat Gluten Film. J. Food Science. Jurnal of food Sciense 58 (1): 206-211

https://id.wikipedia.org/wiki/Plastik, diakses tanggal 20 April 2013.

http://inspirationbioteknologi.blogspot. com/2009/05/pengembangan-bahanplastik.html diakses tanggal 11 Juli 2013 
Karuniastuti, N. (2016). Bahaya Plastik terhadap Kesehatan dan Lingkungan. In Forum Tenologi (Vol. 3, No. 1, pp. 6-14).

Krystyna wrzesniewska, T, Adamiec, J. (2007). Biocomposites With a Content of Keratin from Chicken Feathers. Faculty of Process Engineering, Poland. 223, 90-924.

Lastriyanto A at all, ( 2007) Penentuan koefisien Permeabilitas Edible Film Terhadap Transmisi Uap Air, Gas O2, dan Gas CO2. Malang, Universitas Brawijaya.

Marbun, E. (2012). Sintesis Bioplastik dari Pati Ubi Jalar Menggunakan Penguat Logam Zno dan Penguat Alami Selulosa. Skripsi, Depok: Universitas Indonesia

Nugroho, A., Basito, R., Baskara Katri Anandito.

(2013) Kajian Pembuatan Edible Film Tapioka dengan Pengaruh Penambahan Pektin Beberapa jenis Kuli Pisang Terhadap karakteristik Fisik dan Mekanik, Jurnal Teknosains pangan Vol 2 No , Jurusan Teknologi Hasil Pertanian Universitas
Sebelas Maret.

Prisma wisdawati, 2007 https://repository.ipb. ac.id/.../PKM diakses tanggal 7 Mei 2013. Puastuti, W. (2007) Teknologi Pemprosesan Bulu Ayam Dan Pemanfaatannya sebagai sumber Protein Pakan Ruminansia. Makalah Balai Penelitian Ternak. Bogor.

Rachmawati A, (2009)Ekstraksi dan Karakterisasi Pektin Cincau Hijau (Premna oblongifolia. Merr) Untuk Pembuatan Edible. Skripsi, Fakultas Pertanian Universitas Sebelas Maret.

Syamsu, Khaswar. A.M. Fauzi, L. Hartoto, A. Suryani, N. Atifah. (2015). Karakteristik Bioplastik poli B-Hidroksialkanoat yang Dihasilkan Oleh Ralstonia eutropha Pada Hidrolisat Pati Sagu dengan Pemblastis Isoprofil Palmitat. Bogor: Institut Teknologi Bandung.

Teknologi Pangan dan GIZI, Edible Film. Jurnal Tekno Pangan dan Agroindustri, Volume 1. 1997, Institut Pertanian Bogor. IPB. 